\title{
Neuroprotective dose and safety profile of magnesium sulphate therapy in term neonates with perinatal asphyxia
}

\author{
Raj Prakash ${ }^{1}$ \\ ${ }^{1}$ Dr Raj Prakash, Department of Pediatrics, Mysore Medical College and Research Institute, Mysore, Karnataka, India
}

Address for Correspondence: Dr Raj Prakash, E-mail : rajprakash84@gmail.com

\begin{abstract}
Introduction: Perinatal asphyxia has become a major public health problem accounting for $9 \%$ of total under-5 mortality. It can lead to serious neuro-motor sequelae in survivors. Newer neuroprotective strategies for management of perinatal asphyxia have gained momentum in recent era. Background: To determine the effective dosage regimen and safety profile of intravenous magnesium sulphate as a neuroprotective agent for perinatal asphyxia in term neonates. Materials and methods: 60 term asphyxiated neonates admitted in NICU of a tertiary care teaching hospital were evaluated. Babies were treated as per the standard treatment protocol for perinatal asphyxia. The infants received 250 $\mathrm{mg} / \mathrm{kg}$ per dose intravenous magnesium over 1 hour within 6 hrs of birth, with 2 additional doses repeated at intervals of 24 hours. The heart rate, respiratory rate, blood pressure and oxygen saturation were monitored continuously. A baseline serum magnesium level was measured soon after delivery and two more serum magnesium levels at $24 \mathrm{hr}$ and at $48 \mathrm{hr}$ was measured. Results: The pre intervention baseline serum magnesium level was $1.52( \pm 0.302) \mathrm{meq} / \mathrm{L}$. The serum magnesium level increased from the baseline level of $1.52( \pm 0.302) \mathrm{meq} / \mathrm{L}$ to $2.63( \pm 0.558) \mathrm{meq} / \mathrm{L}$ at 24 hour and 2.72 $( \pm 0.495) \mathrm{meq} / \mathrm{L}$ at 48 hour. The neuroprotective range of serum magnesium is $2.4-5 \mathrm{Meq} / \mathrm{L}$. This dosage regimen will ensure plasma concentration of magnesium in the neuroprotective range for 48 hours. All physiologic variables remained unchanged including heart rate, respiratory rate, blood pressure and oxygen saturation during intervention. Conclusion: Intravenous infusion of 3 doses of magnesium $250 \mathrm{mg} / \mathrm{kg} / \mathrm{dose}$ in first $48 \mathrm{hrs}$ after birth will ensure serum magnesium level in the neuroprotective range. This therapeutic dosage regimen has been found to have the best margin of safety profile in term asphyxiated infants.
\end{abstract}

Keywords: Magnesium sulphate, Perinatal asphyxia, Neuroprotective dose.

\section{Introduction}

Perinatal asphyxia is an important cause of early neonatal death and stillbirth. Approximately 4 million babies die each year during neonatal period. Ninetyeight percent of these neonatal deaths take place in the developing countries. Approximately $44 \%$ of stillbirths occurring globally during intrapartum period are mostly due to perinatal asphyxia [1].

During hypoxia-ischemia, there is an increase in calcium influx into neuronal cells by stimulation of the NMDA (N-methyl-D-aspartate) receptors by excitotoxic aminoacids, mainly glutamate. This increased intracellular calcium, interferes with many enzymatic reactions including the activation of lipases, proteases, endonucleases and phospholipases and the

Manuscript received: $24^{\text {th }}$ Jan 2016

Reviewed: $07^{\text {th }} \mathrm{Feb} 2016$

Author Corrected; $17^{\text {th }} \mathrm{Feb} 2016$

Accepted for Publication: $29^{\text {th }}$ Feb 2016 formation of oxygen free radicals. The accumulation of cytosolic calcium after hypoxia-ischemia has detrimental effects on neuronal cells leading to irreversible brain damage [2].

Magnesium exerts its neuroprotective effect by antagonizing NMDA receptors. The neonatal cortex has fewer NMDA receptors than older subjects with a below normal response to magnesium. This implies that the plasma concentration of magnesium sulphate needed to achieve neuroprotection in neonates will be greater than that in older infants or adults [3, 4]. The present study aims at establishing the optimum dose of magnesium sulphate infusion in term asphyxiated infants in the initial 48 hours of life to ensure a neuroprotective level of magnesium in that crucial period of brain injury. 


\section{Materials and Methods}

The present study was a prospective interventional study conducted in neonates with perinatal asphyxia delivered at Cheluvamba hospital attached to Mysore Medical College \& Research Institute, Mysore, India from November 2011 to February 2012. A minimum sample size calculation of 60 infants with perinatal asphyxia was done with the incidence of perinatal asphyxia of 2/100 live births at our institution at a 0.05 significance level and a power of $80 \%$.

The formula used was $n=z^{2} p q / d^{2}$ where $z=1.96, p=0.02$, $q=1-p, d=0.05$.

Neonates were enrolled after informed consent from parents. The study was approved by the institutional ethical committee.

60 term infants with perinatal asphyxia were selected for the study. The infants were labeled asphyxiated if the following inclusion criteria [5] were met: 1) A sentinel hypoxic event occurring immediately before or during labour. 2) Failure to initiate breath at birth or Apgar score $<7$ at one minute.3) need for resuscitation at birth (positive pressure ventilation or chest compression) 4) moderate or severe hypoxic ischemic encephalopathy \& 5) exclusion of other etiologies.

Neonates with history of maternal magnesium exposure prior to delivery, mothers receiving pethidine or phenobarbitone which may cause depression in baby and neonates with any obvious external congenital malformations were excluded from the study.

The neonates were treated according to the routine NICU protocol for perinatal asphyxia. In addition they received magnesium sulphate intravenous infusion at $250 \mathrm{mg} / \mathrm{kg} /$ dose $(1 \mathrm{ml} / \mathrm{kg} /$ dose in $20 \mathrm{ml}$ of $5 \%$ dextrose solution) over 1 hour within 6 hours of birth with 2 additional doses repeated after 24 hours and later at 48 hours.

During the initial 72 hours of life, heart rate, respiratory rate, blood pressure and oxygen saturation were monitored continuously using Philips SureSigns VM8 pulse oximeter. The neurologic status was assessed daily during the stay. The grade of Hypoxic ischemic encephalopathy [6] (Stage I, Stage II or Stage III), need for respiratory supports, and presence of seizures, multiorgan dysfunction and the time for establishment of full oral feedings were evaluated.

Baseline serum magnesium was measured soon after delivery and two more serum magnesium levels were measured at 24 hours and at 48 hours in both the groups. Serum magnesium was measured using magnesium kit provided by CREST biosystems using Calmagite method. All the statistical methods (descriptive statistics, chi square/contingency coefficient analysis, independent samples t test) were carried out through the SPSS for windows (version 16.0). The $\mathrm{p}$ value $<0.05$ was taken as statistically significant.

\section{Results}

A total of 82 neonates were screened of which 22 neonates were excluded ( 14 neonates had exclusion criteria, 5 parents refused to participate and 3 neonates were discharged against medical advice before completion of intervention). Finally 60 neonates were included in the study. The male to female ratio was 1:1.5. The mean age of mothers was 21.9 years and $73.3 \%$ were primiparas and rest multiparas. Meconium stained amniotic fluid was the most common risk factor for birth asphyxia followed by premature rupture of membranes and prolonged labor. 40 neonates were delivered by normal vaginal delivery and rest by cesarean or assisted vaginal delivery. 56 infants were appropriate for gestational age. Most of the neonate's required endotracheal intubation while resuscitation (63\%). 24 infants had Stage 1, 34 Stage 2 and 2 Stage 3 hypoxic ischemic encephalopathy (HIE)

Table 1: Comparison of serum magnesium levels before and after intervention

\begin{tabular}{|l|l|}
\hline Intervention time & Mean serum Magnesium meq/L \\
\hline Preintervention baseline $\mathrm{Mg}$ level & $1.52 \pm 0.302$ \\
\hline Postintervention $\mathrm{Mg}$ level- $24 \mathrm{hrs}$ & $2.63 \pm 0.558$ \\
\hline Postintervention $\mathrm{Mg}$ level- $48 \mathrm{hrs}$ & $2.63 \pm 0.558$ \\
\hline
\end{tabular}

The pre intervention baseline serum magnesium levels were $1.52( \pm 0.302) \mathrm{meq} / \mathrm{L}$. The serum magnesium level increased from the baseline level of $1.52( \pm 0.302) \mathrm{meq} / \mathrm{L}$ to $2.63( \pm 0.558) \mathrm{meq} / \mathrm{L}$ at 24 hour and $2.72( \pm 0.495) \mathrm{meq} / \mathrm{L}$ at 48 hour. 
After intervention, significant rise in mean serum magnesium levels was noted. The post intervention mean serum magnesium level was more than $2.4 \mathrm{Meq} / \mathrm{L}(1.2 \mathrm{mmol} / \mathrm{L})$ which is in therapeutic and neuroprotective range.

All physiologic variables remained stable including heart rate, respiratory rate and oxygen saturation during infusion period and for initial 72 hours. Mean arterial blood pressure of study cases were $45.6 \pm 3.22$ during first 72 hours. No adverse effects related to elevated levels of magnesium were noted in any of the neonates.

Table 2: Vitals during initial 72 hrs of admission

\begin{tabular}{|l|l|}
\hline Vitals & Mean \pm SD \\
\hline Heart Rate/min & $147 \pm 14.57$ \\
\hline Respiratory Rate /min & $46 \pm 7.89$ \\
\hline Oxygen saturation (\%) & $96.6 \pm 4.897$ \\
\hline Mean arterial blood pressure $(\mathrm{mm} \mathrm{Hg})$ & $45.6 \pm 3.22$ \\
\hline
\end{tabular}

\section{Discussion}

The vulnerability of brain to hypoxic ischemia may be accounted for by the central neurotoxicity of the endogenous excitatory amino acid neurotransmitter, glutamate, released into the extracellular space. Glutamate appears to be a remarkably potent and rapidly acting neurotoxin. The transient release of only a small fraction of the intracellular stores of glutamate into the extracellular space can damage neurons. The glutamate neurotoxicity may be largely mediated by a toxic influx of extracellular calcium. Intense glutamate exposure produces immediate neuronal swelling, and is probably due to the entry of sodium, chloride, and water into the cells [7].

The glutamate neurotoxicity may be blocked by antagonist compounds, in particular those effective against the N-methyl-D aspartate (NMDA) subtype of glutamate receptor-ionophore complexes like MK-801, magnesium, ketamine, dextrorphan. A number of different laboratories have now confirmed and extended these results with various NMDA antagonists including magnesium. Several reports describe how the ability of magnesium to block NMDA mediated responses changes as the brain develops, and further suggest that these changes may be regionally dependent $[8,9]$.

Secondary injury to the post hypoxic neonatal brain can occur over a period that may last as long as 72 hours. The present study used a loading dose of $250 \mathrm{mg} / \mathrm{kg}$ magnesium, followed by two further infusions of same dose 24 hours apart. Based on the pharmacokinetics and estimates of plasma half life of magnesium sulphate as reported by Levene $\mathrm{M}$ et al in 1995 [10], this dosage regimen will ensure plasma concentration of magnesium in the neuroprotective range for 72 hours. The neuroprotective range of serum magnesium is $2.4-$
$5 \mathrm{Meq} / \mathrm{L}(1.2-2.5 \mathrm{mmol} / \mathrm{L})$.In the present study, the post intervention mean serum magnesium level of cases was more than $2.4 \mathrm{Meq} / \mathrm{L}(1.2 \mathrm{mmol} / \mathrm{L})$ which is in therapeutic and neuroprotective range.

Bhat MA et al in 2009 used $250 \mathrm{mg} / \mathrm{kg} / \mathrm{dose}$ magnesium, administered thrice to the study group and placebo to the control group. The levels for the treatment group were higher at 1, 23, 25, 47, 49, and 72 hours. In the treatment group, the mean serum magnesium concentration increased from $0.77 \mathrm{mmol} / \mathrm{L}$ at 0 hour to $1.5 \mathrm{mmol} / \mathrm{L}$ within 1 hour after the first dose, from 1.2 to $2.2 \mathrm{mmol} / \mathrm{L}$ within 1 hour after the second dose, and from 1.4 to $2.8 \mathrm{mmol} / \mathrm{L}$ within 1 hour after the third dose of magnesium sulfate. Therefore, the mean serum magnesium concentration remained more than or equal to $1.2 \mathrm{mmol} / \mathrm{L}$ during the initial 72 hours after the first infusion [11].

In the study conducted by Ichiba $\mathrm{H}$ et al in 2002 using $250 \mathrm{mg} / \mathrm{kg} /$ dose magnesium for the treated group, mean serum magnesium concentration increased from 0.8 $\mathrm{mmol} / \mathrm{L}$ to $2.7 \mathrm{mmol} / \mathrm{L} 1 \mathrm{~h}$ after the first infusion and also increased from $1.3 \mathrm{mmol} / \mathrm{L}$ to $2.9 \mathrm{mmol} / \mathrm{L}$ and from $1.4 \mathrm{mmol} / \mathrm{L}$ to $3.2 \mathrm{mmol} / \mathrm{L}$ at $1 \mathrm{~h}$ after the second and third infusions, respectively. Thus, the mean serum Magnesium concentration remained at or above 1.3 $\mathrm{mmol} / \mathrm{L}$ during the $72 \mathrm{~h}$ following the first infusion [12].

In the study conducted by Ichiba $\mathrm{H}$ et al 2006 the mean serum Magnesium concentration remained at least 1.3 $\mathrm{mmol} / \mathrm{L}$ during the $72 \mathrm{~h}$ following the first infusion of magnesium [13].

In the study conducted by Gathwala G et al in 2006 with same dose, serum magnesium levels in the study 
and the control group were comparable at $0 \mathrm{hr}$ but were significantly higher $(\mathrm{p}<0.001)$ in the study group at 3,6 , 12, 24, 48 and 72 hours. The serum magnesium levels in the study group after administration of magnesium ranged between $1.47( \pm 0.9)$ and $1.92( \pm 0.05) \mathrm{mmol} / \mathrm{ltr}$ during the first 72 hours of life. In the control group they ranged between $0.78( \pm 0.04)$ and $0.88( \pm 0.03)$ $\mathrm{mmol} / \operatorname{ltr}[14]$.

In study of Levene $\mathrm{M}$ et al in 1995, one group received $250 \mathrm{mg} / \mathrm{kg}$ while other group received $400 \mathrm{mg} / \mathrm{kg}$. The drug was administered only once. The changes in serum Magnesium after an infusion of $250 \mathrm{mg} / \mathrm{kg}$ to 8 neonates was as follows: Serum Magnesium increased from a mean of $0.71 \mathrm{mmol} / 1$ to $2.42 \mathrm{mmol} / 1$ at one hour, $1.52 \mathrm{mmol} / \mathrm{l}$ at 12 hours, and $1.12 \mathrm{mmol} / \mathrm{l}$ at 24 hours [10].

So the present study was similar to all other previous studies with respect to dose and the level of serum magnesium before and after intervention for both cases and controls.

The present study was similar to that done by Bhat MA et al with respect to mean arterial blood pressure which remained unchanged over 72 hours after birth during which magnesium was infused [11].

In the study conducted by Gathwala $\mathrm{G}$ et al in 2006 the mean arterial blood pressure showed some fall from the initial $47.1 \pm 9.54 \mathrm{~mm} \mathrm{Hg}$ to $44.5 \pm 5.6 \mathrm{~mm} \mathrm{Hg}$ at one hour, but it was not significant [14].

In the present study all physiologic variables remained unchanged including heart rate, respiratory rate and oxygen saturation before and after intervention for all subjects. This was similar to the observation done by Bhat MA et al in 2009, Ichiba H in 2006 and 2002, Gathwala $\mathrm{G}$ et al in 2006 and Levene $\mathrm{M}$ et al in 1995 $[10,11,12,13,14]$.

\section{Conclusions}

Intravenous infusion of 3 doses of magnesium $250 \mathrm{mg} / \mathrm{kg} / \mathrm{dose}$ in first $48 \mathrm{hrs}$ after birth will ensure serum magnesium level in the neuroprotective range for 72 hours. The neuroprotective range of serum magnesium is $2.4-5 \mathrm{Meq} / \mathrm{L}(1.2-2.5 \mathrm{mmol} / \mathrm{L})$.In the present study, the post intervention mean serum magnesium level of cases was more than $2.4 \mathrm{Meq} / \mathrm{L}$ (1.2 $\mathrm{mmol} / \mathrm{L})$ which is in therapeutic and neuroprotective range.
This therapeutic dosage regimen has been found to have the best margin of safety profile in term asphyxiated infants. No infants experienced significant adverse effects. All physiological variables including heart rate, respiratory rate and oxygen saturation remained stable during the study period.

Funding: No funding sources

Conflict of interest: None declared

Ethical approval: The study was approved by the Institutional Ethics Committee.

\section{References}

1. World Health Organization. Perinatal mortality: A Listing of Available Information.FRH/MSM.96.7.Geneva:WHO,1996.

2. Perlman JM. Summary proceedings from the neurology group on hypoxic-ischemic encephalopathy. Pediatrics. 2006 Mar;117(3 Pt 2):S2833.

3. Gathwala G. Neuronal protection with magnesium. Indian J Pediatr. 2001 May;68(5):417-9.

4. Chahal H, D'Souza S, Barson A, Slater P. Modulation by magnesium of N-methyl-D-aspartate receptors in developing human brain. Archives of Disease in Childhood - Fetal and Neonatal Edition. 1998; 78(2):F116-F120.

5. Antonucci R, Porcella A, Pilloni MD. Perinatal asphyxia in the term newborn. $\mathrm{J}$ Pediatr Neonat Individual Med. 2014; 3(2):e030269. doi: 10.7363/030269.

6. Sarnat HB, Sarnat MS. Neonatal encephalopathy following fetal distress. A clinical and electroencephalographic study. Arch Neurol. 1976 Oct;33(10):696-705.

7. Sinha SK, Singh J. Newer concepts and approaches to neonatal brain asphyxia. Indian J Pediatr. 1998 JanFeb;65(1):55-62.

8. Choi DW, Rothman SM. The role of glutamate neurotoxicity in hypoxic-ischemic neuronal death. Annu Rev Neurosci. 1990;13:171-82.

9. Haddad JJ. N-methyl-D-aspartate (NMDA) and the regulation of mitogen-activated protein kinase (MAPK) signaling pathways: A revolving neurochemical axis for 
therapeutic intervention? Progress in Neurobiology. $2005 ; 77: 252-282$.

10. Levene M, Blennow M, Whitelaw A, Hankø E, Fellman V, Hartley R. Acute effects of two different doses of magnesium sulphate in infants with birth asphyxia. Arch Dis Child Fetal Neonatal Ed. 1995 Nov;73(3):F174-7.

11. Bhat MA, Charoo BA, Bhat JI, Ahmad SM, Ali SW, Mufti MU. Magnesium sulfate in severe perinatal asphyxia: a randomized, placebo-controlled trial. Pediatrics. 2009 May;123(5):e764-9. doi: 10.1542/peds.2007-3642. Epub 2009 Apr 6.
12. Ichiba H, Tamai H, Negishi H, Ueda T, Kim T, Sumida $\mathrm{Y}$ et al. Randomized controlled trial of magnesium sulfate infusion for severe birth asphyxia. Pediatrics International. 2002; 44(5):505-509.

13. Ichiba H, Yokoi T, Tamai H, Ueda T, Kim TJ, Yamano T. Neurodevelopmental outcome of infants with birth asphyxia treated with magnesium sulfate. Pediatr Int. 2006 Feb;48(1):70-5.

14. Gathwala G, Khera A, Singh I. Magnesium therapy in birth asphyxia. Indian J Pediatr. 2006 Mar;73(3):20912.

\section{How to cite this article?}

Raj Prakash. Neuroprotective dose and safety profile of magnesium sulphate therapy in term neonates with perinatal asphyxia: Int J Pediatr Res 2016;3(2):119-123. doi:10.17511/ijpr.2016.i02.09. 